\title{
The Receipt-Based Constructive Trust: a Case Study of Personal and Proprietary RESTITUTION IN THE SUPREME COURT
}

\author{
MiChAEL BRYAN*
}

This article analyzes the Supreme Court of Canada's treatment of the receipt-based consiructive trust in the companion cases of Gold $v$. Rosenberg and Citadel General Assurance Co. $\nu$. Lloyds Bank Canada The author discusses the liability of those who participate in a breach of fiduciany duty to be held accountable as constructive trustees. He criticizes the Supreme Court's decisions for being too equitable and, while correctly characterizing equitable recipient liability as restimutionary, for failing 10 adhere sufficiently to restitutionary principles in their reasoning. In addition, the author discusses different approaches used by the courts in determining the degree of knowledge necessary to hold a recipient of property liable as a consiructive trustee. Ulimately, this article determines the Supreme Court's failure to understand the juristic nature of the receipt-based constructive trust results in continued confusion in the treatment of the constructive trust.
L'auteur analyse le traitement que la Cour supreme du Canada a réservé à la fiducie d'interprétation fondé sur la réception dans les causes Gold c. Rosenberg et Citadelle (La), Cie d'assurances générales $\mathrm{c}$. Banque Lloyds du Canada. Il parle des tiers à une fiducie susceptibles d'être senus responsables du manquement à une obligation fiduciaire à titre de fiduciaires par interprétation. Selon lui, les décisions de la Cour suprême sont trop équitables et, bien que caractérisant correctement la responsabilité du destinataire en termes de restitution. leur raisonnement n'adhire pas suffisamment aux principes de la restitution. I. auteur examine différentes approches utilisées par les tribunaux pour determiner le degré de connaissance requis chez le thers et imposer la responsabilité fondée sur la aréception en connaissance de causes. Selon l'auteur, le fait que la Cour supreme ne comprenne pas la nature juridique de la fiducie d'interprétation fondée sur la réception est $\dot{a}$ l'origine d'une confusion qui perdure.

\section{Table of Contents}

I. INTRODUCTION .....................73

1I. THE FACTS OF GOLD v. ROSENBERG AND CTTADEL GENERAL

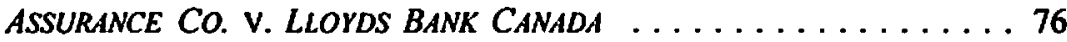

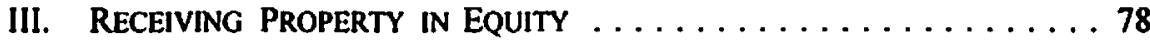

IV. KNOWLEDGE, NOTICE AND STRICT LIABILITY $\ldots \ldots \ldots \ldots \ldots .83$

A. THE DISHONESTY, OR CONSCIENCE, APPROACH $\ldots \ldots \ldots 85$

B. THE PROPERTY APPROACH $\ldots \ldots \ldots \ldots \ldots \ldots \ldots . \ldots 87$

C. Holding RECIPIENTS STRICTIY LIABLE $\ldots \ldots \ldots \ldots \ldots \ldots 90$

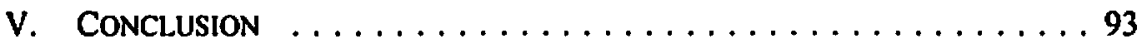

\section{INTRODUCTION}

The intellectual fashions of legal writers are as fickle and transient as other fashions, but for writers on equity and restitution the constructive trust has never lost its allure. It is probably still true to say that the family home constructive trust' and the constructive trust imposed on property acquired by fiduciaries in breach of their

Reader and Associate Dean of Law, University of Melbourne.

Pettkus v. Becker (1980), 117 D.L.R. (3d) 257 (S.C.C.). See P.D. Maddaugh \& J.D. McCamus,

The Law of Restitution (Aurora, Ont.: Canada Law Book, 1990) c. 27. 
obligations of loyalty ${ }^{2}$ attract the most attention. But other types of constructive trust are coming into clearer focus. Over the last decade a growing body of case law in Canada and other common law jurisdictions has concerned the liability to account as constructive trustees of those who participate in a breach of fiduciary duty. The proliferation of reported cases has been accompanied by some original and challenging analysis into the nature and purpose of imposing equitable liability on the secondary actors in fiduciary wrongdoing.

The reasons for the "discovery" by lawyers and academic writers of equitable participatory liability are not hard to find. The "boom and bust" economic conditions of the late 1980s, overtaken by the recession of the early 1990s, has situated this form of constructive trusteeship squarely within an insolvency framework: a finding that a bankrupt has committed a breach of fiduciary obligation enlarges the range of potential defendants to include other solvent, or at least insured, ancillary parties implicated in the wrongdoing. ${ }^{3}$ If the fiduciary is a company in default of its obligations as trustee or agent, its directors can be sued as accessories to the corporate wrongdoing without challenging the conventional wisdom on corporate personality. ${ }^{4}$ Related to this has been the growth of international fraud and money laundering, caused in part by the reduction or elimination of exchange controls world-wide." Civil recovery from secondary actors in a fraud, such as banks, solicitors and accountants, who are amenable to the jurisdiction of the court, is often a more realistic prospect than pursuing a jurisdiction-skipping and sometimes judgment-proof fraudster. At a more conceptual level, a consequence of the increased readiness of Canadian courts to characterize wrongdoers as fiduciaries ${ }^{6}$ has been the creation of an even larger army of additional participants in the wrongdoing whose resources can be tapped through the medium of constructive trusteeship.?

Over a century ago Lord Selborne L.C. in Barnes v. Addy ${ }^{8}$ expounded the principles of equitable participatory liability with all the magisterial authority and self-belief that

LAC Minerals v. International Corona Resources (1989), 61 D.L.R. (4th) 14 (S.C.C.); Hodgkinson v. Simms (1994), 117 D.L.R. (4th) 161 (S.C.C.). See Maddaugh \& McCamus, ibid., c. 25. The collapse of international stock markets in October 1987, resulting in an abrupt reduction in the value of shares required to finance transactions entered into by fiduciaries, produced a flurry of cases when some of the fiduciaries turned to unauthorized methods of raising capital: Eagle Truss v. SBC Securities, [1992] 4 All. E.R. 488 (Ch. Div.), Cowan de Groot Properties v. Eagle Trust, [1992] 4 All. E.R. 700 (Ch. Div.). Air Canada v. M \& L Travel (1993), 108 D.L.R. (4th) 592 (S.C.C.) [hereinafter Air Canada]; Royal Brunei Airlines v. Tan, [1995] 2 A.C. 378.

S Agip (Africa) v. Jackson, [1990] I Ch. 265; Polly Peck International v. Nadir (No. 2), [1992] 4 All. E.R. 769 (C.A.); El Ajou v. Dollar Land Holdings, [1993] 3 All. E.R. 717 (Ch. Div.). P. Birks, ed., Laundering and Tracing (Oxford: Clarendon Press, 1995) is a volume of essays devoted to analyzing the restitutionary aspects of money laundering. This trend is usefully discussed by J.D. McCamus, "Prometheus Unbound: Fiduciary Obligation in the Supreme Court of Canada" (1997) 28 Can. Bus. L.J. 107.

Many participants could be reached through the medium of common law recovery, but this is more rarely discussed. For a review of accessory liability at common law, see $M$. Tugenhadt, Q.C., "Assisting a Breach of Duty by a Fiduciary: the Common Law and Money Laundering" in F. Rose, ed., Restitution and Banking Law (Oxford: Mansfield Press, 1998) 135. 
a Victorian master of equity can command. Placing to one side cases of fraud and liability of trustees 'de son tort' (who act as trustees even though not appointed as such), Lord Selborne identified" two situations in which "strangers" to a breach of trust or other fiduciary wrongdoing are accountable as constructive trustees. The first is where strangers "receive and become chargeable with some part of the trust property"; 10 the second occurs where "they assist with knowledge in a dishonest and fraudulent design on the part of the trustees." "No authority was cited in support of this division of accessory liability which, without any considered analysis has been applied ever since, replacing a more elaborate doctrinal structure which had existed prior to Barnes v. Addy. ${ }^{12}$

Canadian courts have adhered with remarkable fidelity to the scheme laid down by Lord Selborne. ${ }^{13}$ This contrasts with the United States experience where many jurisdictions have abandoned the jurisprudence of Barnes $v$. Addy in favour of a broader, if vaguer, notion of participatory liability. ${ }^{14}$ Whatever Lord Selborne may have had in mind when he distinguished the equitable liability of recipients from the liability of those who assist without receiving the proceeds of wrongdoing, it is a measure of his sympathetic intuition for the role of equitable principle that the distinction has proved durable and is accepted as reflecting important differences in the remedial objectives of equity in imposing liability through the mechanism of a constructive trust. In Air Canada v. M.L. Travel the Supreme Court of Canada had occasion to review the principles for holding assisters accountable as constructive trustee. The assister was held to be under a personal obligation to pay compensation to the victim of the fiduciary wrongdoing. ${ }^{\text {is }}$ The substance of this head of liability, obscured by the appellation "constructive trust," is that an assister has committed an equitable tort for which compensation, assessed in accordance with the rules for assessing equitable compensation, is payable.

In the companion cases of Gold v. Rosenberg ${ }^{16}$ and Citadel General Assurance v. Lloyds Bank Canada, ${ }^{17}$ it was the spotlight's turn to fall on the receipt-based

9

10

11

12

lbid. at 251-52.

lbid.

lbid. at 252.

C. Harpum, "The Stranger as Constructive Trustec" (1986) 102 L. Q. Rev. 114.

Perhaps with too much fidelity. In Air Canada, supra note 4, the Supreme Court held, McLachlin J. reserving her opinion, that an assister can only be held liable as constructive trustee if the original breach of fiduciary duty was dishonest and fraudulent. The holding in the case was based on the formulation of assister liability by Lord Selborne in Barnes v. Addy, supra note 8. In Royal Brunei Airline v. Tan, supra note 4, the Privy Council undertook a more wide-ranging review of the authorities and held that the breach of duty need not be fraudulent and could be innocent. This is an issue which the Supreme Court might usefully revisit should a suitable opportunity arise.

W.F. Fratcher, Scott on Trusts, vol, 4 (Boston: Little, Brown and Co., 1989) at paras. 321-29. In some states the liability of banks as participants is governed by the Unjform Fiduclaries Act, ibid. at paras. 324-35.

Ibid. at para. 606, lacobucci J. The reservations expressed by McLachlin J. at 594-96 do not relate to this characterization.

(1997), 152 D.L.R. (4th) 385 (S.C.C.) (hereinafter Gold v. Rosenberg).

(1997), 152 D.L.R. (4th) 411 (S.C.C.) [hereinafler Citadel]. 
constructive trust. The Supreme Court conceptualized recipient liability as being restitutionary; in other words, ${ }^{18}$ it reverses the unjust enrichment of the party who has received the proceeds of fiduciary wrongdoing. The purpose of this article is to examine more closely what this restitutionary conceptualisation ought to mean. It will be suggested that, to put it bluntly, the judgments of the Supreme Court are too equitable and insufficiently restitutionary in their reasoning. They analyze at length the meaning of receipt in equity, without properly considering whether "receipt" is synonymous with "enrichment." The question, which has preoccupied courts of equity for many years to the point of distraction, as to the degree of knowledge required to hold a recipient liable as constructive trustee, has yet again received extended treatment, whereas the "injustice" which entitles a plaintiff to restitution is scarcely touched upon. Finally, the judgments misunderstand the nature of receipt-based constructive trusteeship. Recipient liability is perceived by the Court as being proprietary, imposed in order to resolve disputes as to title to property. The reality of this species of constructive trust is, however, that it is not proprietary; as in the case of assister liability, the label "constructive trust" is misleading. A successful plaintiff is entitled to a personal remedy, which it is not unreasonable to characterize as the equitable equivalent of the common law action for money had and received. The Supreme Court decision throws into sharp relief many of the problems courts experience in transforming the comfortable categories of traditional equity doctrine into an intellectually convincing framework of unjust enrichment.

\section{THE FACTS OF GOLD v. ROSENBERG AND Citadel GENERAL ASSURANCE v. LlOYDS BANK, CANADA}

Although treated by the Supreme Court as companion cases, Gold v. Rosenberg and Citadel differ in their basic fact patterns and in many of the issues they raise. In Gold v. Rosenberg, an uncle and nephew were executors and equal beneficiaries of the residue of an estate. The assets of the estate consisted primarily of commercial real estate companies. Not long after the death of the testator the nephew signed a power of attorney which permitted his uncle to manage the estate companies. In addition to these companies, the uncle, with his wife, owned all the shares of another company, Trojan. Trojan owed money to the Toronto Dominion Bank. Wanting to raise money for Trojan's business purposes, the uncle negotiated a loan of $\$ 3.9$ million from the bank in return for a guarantee from one of the estate companies, supported by a mortgage over properties belonging to the estate and a postponement in favour of the bank of a mortgage held by one of the estate companies over property owned by Trojan. The loan agreements required the nephew's signature, in his capacity as director of the estate companies, to the guarantee secured by the companies. The nephew duly signed the documents, albeit after the bank had advanced the loans to Trojan. A month later the nephew revoked the power of attorney in favour of his uncle, and later brought altemative claims against the bank for having knowingly assisted in a breach of

But see L. Smith, “W(h)ither Knowing Receipt?" (1998) 114 L.Q. Rev. 398 for the argument that a restitutionary analysis of the knowing receipt constructive trust does not necessarily presuppose that it is based on unjust enrichment. 
fiduciary duty, and for having received property with the knowledge of the uncle's prior breach of fiduciary duty.

The trial judge found the uncle had committed a breach of fiduciary duty by causing estate assets, which he held as to fifty percent on trust for the nephew pursuant to the power of attorney, to be applied as security to raise money for Trojan. ${ }^{19}$ Accepting, for the purposes of analysis, that the uncle had committed a fraudulent and dishonest breach of trust, ${ }^{20}$ the Supreme Court unanimously held the bank not liable for knowingly assisting the breach of trust because it had not been proved that the bank's officers had actual knowledge of the uncle's fraud. ${ }^{21} \mathrm{~A}$ majority of the Court (Sopinka, McLachlin and Major JJ. dissenting on this issue) held the bank had received property, namely, the estate properties constituting security for the bank loan. But a differently constituted majority (lacobucci, La Forest and Cory JJ. dissenting) held the bank was not liable as a constructive trustee since "knowing what it knew, [it] acted reasonably in the circumstances."22

In Citadel, a company called Drive On was in the business of selling insurance to auto dealers. After paying commissions and settling claims under the policies, Drive On remitted the balance of the premiums to Citadel, the underwriter of the insurance policies. Pending the remission of the premiums, Drive On banked the money in its account at Lloyds Bank. Its parent company, International Warranty Company Ltd. (IWC), gave instructions that all funds in the Drive On account should be transferred at the end of each business day to IWC's account, held at the same branch of the bank. The amounts transferred helped to reduce IWC's overdraft. After Drive On and IWC went into liquidation, Citadel sued the bank for the outstanding premiums, amounting to $\$ 633,622.84$, which Drive On had failed to account to Citadel. Marshall J., at first instance, held that a relationship of trust existed between Citadel and Drive On. ${ }^{23}$ The Supreme Court held the bank was not liable for having knowingly assisted in a breach of fiduciary obligation because it had only constructive knowledge of the breach of obligation. This was an insufficient basis for imposing accessory liability. ${ }^{24}$ But the bank was held liable for having knowingly received the premiums collected by Drive On since it had constructive knowledge of the company's breach of trust, such knowledge being enough to justify the imposition of a receipt-based constructive trust. The factual basis for the finding of constructive knowledge was summarized as follows:

19 Ontario Court of Justice (General Division), [1993] O.J. No. 2994 (QL), Haley J.

20 Held to be a precondition of liability for knowing assistance in Air Canada, supra note 4.

21 Supra note 16.

$22 \quad$ Ibid. at 406, Sopinka J.

23 Supra note 17 at 416 . The finding was based in part on s. 124(1) of the Insurance Act, R.S.A. 1980, c. I-5 which provides that an agent or broker who negotiates a contract of insurance with an insurer and receives insurance premiums for that contract is deemed to hold the premiums in trust for the insurer. 
In light of the Bank's knowledge of the nature of the funds, the daily emptying of the account was in the trial judge's view "very suspicious." In these circumstances, a reasonable person would have been put on inquiry as to the possible misapplication of the trust funds. ${ }^{25}$

Although "knowing receipt" and "knowing assistance" liability are both discussed in the judgments, only the former head of equitable liability will be considered in this article.

\section{Receiving Property in Equity}

An issue in both cases was whether the respective banks had received property. In Ciladel, Lloyds Bank had received money collected by Drive On, representing premiums paid by auto dealers. In Gold v. Rosenberg, the bank had received a guarantee given by one of the estate companies. ${ }^{26}$ The guarantee was supported by a mortgage over property owned by one company and a postponement in favour of the bank of a mortgage held by the other company over property owned by Trojan. These different types of assets require separate consideration.

In Citadel, La Forest J. adopted a distinction, previously drawn by Millett J. in Agip (Africa) v. Jackson, ${ }^{27}$ between property which has been beneficially received and nonbeneficially received property. Millett J. explained the distinction as follows:

The essential feature of [knowing receipt liability] is that the recipient must have received the property for his own use and benefit. That is why neither the paying nor the collecting bank can normally be brought within it. In paying or collecting money for a customer the bank acts only as his agent. It is otherwise, however, if the collecting bank uses the money to reduce or discharge the customer's overdraft. In doing so it receives the money for its own benefit.

Applying this test, Lloyds Bank had received a benefit from being able to set-off the deposit of insurance premiums against IWC's overdraft. ${ }^{29}$

The point of the distinction is easy to see. It enables a bank to escape liability, without the necessity for courts to engage in complex and time consuming inquiries into states of knowledge, where its participation has been limited to acting as a temporary depository of funds. The bank can set up its agency status as a defence to the restitutionary claim, compelling the plaintiff to redirect its claim against the bank's customer.

While the policy underlying the agency defence is sound, it is unclear whether establishing a historically dubious distinction between beneficially received and non-

Ibid. at 437, La Forest J.

The company which was to give the guasantee was not specified in the original agreement between the uncle and the bank: supra note 16 at 388.

Supra note 5. See also P.J. Millett, "Tracing the Proceeds of Fraud" (1991) 107 L.Q. Rev. 71 at 83.

Agip(Africa) v. Jackson, supra note 5 at 292.

Supra note 17 at 423 , La Forest J. 
beneficially received money is the best way of effectuating it. ${ }^{30}$ In the classic authority on banking law, Foley v. Hill, ${ }^{31}$ Lord Cottenham L.C. declared that all money received by a bank was its own money and could be applied by the bank in any lawful way for its own commercial purposes. "The money placed in the custody of a banker is, to all intents and purposes, the money of the banker, to do with it as he pleases." 32 Lord Cottenham's principle applies to all money received by a bank, including trust money, unless it has been received upon the (highly unusual) terms that it is to be neither mixed with the bank's other money nor invested for profit. Banks are in the business of making money, irrespective of the source of the money, with a view to yielding profit for the institution, as well as interest for the customer. To distinguish between "beneficially" and "non-beneficially" received money is to assert a distinction that reflects neither the law nor the practice of banking.

The significance of the distinction is most clearly seen in cases involving the application of trust (or other fiduciary) money to reduce overdrafts. A bank which applies trust money deposited by its customer to reduce the customer's overdraft is said to have beneficially received (or applied) the money. Conversely, trust money paid into an account in credit has not been beneficially received by the bank. The distinction cuts somewhat awkwardly across the equitable principles distinguishing recipient liability from that of assisters. Trust money paid into an overdrawn bank account has been "received" by the bank, which, according to Ciladel and Gold v. Rosenberg, must account for the money received on the basis of its actual or constructive knowledge. On the other hand, where trust money has been paid into an account which enjoys a healthy balance, the bank can only be held liable as constructive trustee on the basis of "knowing assistance," which requires proof of dishonesty. ${ }^{31}$ If the trust money paid into an overdrawn account not only discharges the overdraft but also places the account in credit, it has been held that any equitable constructive trusteeship imposed on the bank by reason of its application of the money will be partly "receipt-based" and partly "assistance based," each necessitating proof of different standards of knowledge. ${ }^{34}$ Where banks are defendants, therefore, the distinction between the restitutionary liability of a recipient and the compensatory liability of a bank as assister is seemingly dictated by the state of a fiduciary's bank account at the time the trust money is paid in.

The case law on beneficial receipt assumes the application of trust money to reduce an overdraft is financially advantageous to a bank. This will certainly be the case if the

For a more detailed analysis of the agency defence see M. Bryan, "Recovering Misdirected Money From Banks: Ministerial Receipt at Law and in Equity" in Rose, ed,, supra note 7, 161 at 180-87 [hereinafter Bryan, "Recovering Misdirected Money"]. [1848] II H.L.C. 28.

Ibid. at 36.

Air Canada, supra note 4.

Lankshear v. ANZ Banking Group, [1993] I N.Z.L.R. 481. In England the "beneficialnon beneficial" receipt distinction has also complicated analysis of international banking transactions, where a currency exchange, but not a currency transfer without exchange, has been held to constitute a beneficial receipt: Polly Peck International v. Nadir (No. 2), supra note 5. See M. Bryan, Recovering Misdirected Money from Banks, supra note 30 at 182-83. 
customer is doubtfully solvent. But, if the customer is clearly solvent and the overdraft has been arranged for sound commercial reasons, the discharge or reduction of the overdraft may well be disadvantageous to the bank, and it thereby loses the benefit of interest and charges payable on the overdrawn account. This point has been noted by the Australian High Court:

|TThe proposition that a financial institution which makes profits by lending money at interest is better off whenever a corporate customer, which is not known to be insolvent, reduces its use of an overdraf facility which has been made available on commercial terms sounds somewhat strangely in modern cars."

What is needed in this area is a defence which enables banks to escape liability when their only involvement in fiduciary wrongdoing is that of an agent transmitting funds, but which does not rest on the commercially suspect distinction between beneficial and non-beneficial receipt.

It so happens that just such a defence is available to banks, as it is to other agents, at common law. In older cases the defence went by the name of "payment over." Its contemporary designation is "ministerial receipt." 36 The elements of the defence are as follows:

(a) the recipient must have received property as an agent and not in the capacity of principal;

(b) the agent must have acted in good faith and without notice of the true owner's claim to the property; and

(c) the agent must have paid over the property to the principal.

Some controversy surrounds the third requirement. It has been argued that an agent should be able to establish ministerial receipt even in the absence of a payment over to the principal. ${ }^{37}$ The controversy is not immediately relevant in the banking context where, in all reported cases in which a bank has received money as agent, it has accounted to the customer for the money. ${ }^{38}$

Ministerial receipt is a well established defence. ${ }^{39}$ It has long operated to afford agents a defence to actions for money had and received in respect of mistaken or fraudulent payments. There are strong arguments for extending its application to (H.C. of A.).

*. Accounts of the defence can be found in Lord Goff of Chieveley \& G. Jones, The Law of Restitution, 4th ed. (London: Swcet \& Maxwell, 1993) at 480-86; W. Swadling. "The Nature of Ministerial Receipt" in P. Birks, ed., Laundering and Tracing (Oxford, Clarendon Press, 1995) 243 at 253-59 and P. Birks, "Overview: Tracing. Claiming and Defences" in Birks, ed., ibld., 290 at 341-47 [hereinafter Birks, "Overview"].

" Sec Birks, "Overview," ibid. at 344-47.

" Bryan, "Recovering Misdirected Money From Banks," supra note 30 at 171.

3v The classic exposition of principle is that of Lord Mansfield in Buller v. Harrison (1777), 2 Cowp. 565; 98 E.R. 1243. 
equitable claims in the modern law of restitution which seek to rationalize claims and defences on both sides of the jurisdictional divide. Money should be treated as having been received by a bank, for the purposes of imposing a receipt-based constructive trust, whether the customer's account is in credit or in overdraft at the time the trust money is paid. No distinction should be drawn in this regard between beneficial and non-beneficial receipt. However, a bank should be permitted to defeat a claim to constructive trusteeship by establishing that it was a ministerial recipient, in accordance with the criteria set out above. To extend this common law defence to equity should not be condemned as an impermissible fusion of law and equity when the construction of a rational law of restitution favours such an extension.

In Gold v. Rosenberg, the conceptual stumbling block was property, not receipt. The imposition of a receipt-based constructive trust presupposes that at some point the defendant has received legally recognized property. But even though the defendant has received property she will not have title to it at the time of action. The constructive trust does not attach to specific property belonging to the defendant. It is a formula for the award of a personal restitutionary remedy for the value of the plaintiff's property received ("value received") by the defendant and subsequently dissipated or transferred to some other party. ${ }^{40}$ If the defendant has title to the property, or to some substitute for the property, at the time of action, recourse to the receipt-based constructive trust is unnecessary, since the plaintiff can follow or trace the property, and obtain proprietary restitution by way of an equitable lien, or some form of the remedial trust. ${ }^{41}$ Nevertheless, even though a receipt-based constructive trust is a formula for personal liability, the existence of property to which the plaintiff had title is a threshold requirement for the imposition of the constructive trust.

It will be recalled that in Gold $v$. Rosenberg three judges considered that a guarantee supported by collateral mortgages did not constitute property. The grounds for denying proprietary status were explained by Sopinka J.:

A guarantee is a contract whose performance is contingent on the default of the principal debtor.... The guarantor is liable to make good the debts of the principal debtor. If the guarantor supports the guarantee with a mortgage on real property, the creditor only enjoys, at best, a contingent interest in that property. The guarantee supported by the mortgage is no more than a contractual undertaking by the guarantor that, if the principal debtor defaults and the guarantor cannot make good the debt from his or her other assets, the creditor will receive the trust property. The mongage is security for the performance of the contractual provision cmbodied in the guarantee. ${ }^{42}$

Iacobucci J., speaking for the majority of the Supreme Court on this issue, characterized the guarantee as property on the basis of the security supporting it.

This was the case in Cisadel where the insurance premiums collected by Drive On on behalf of Citadel had been applied to reducing IWC's indebtedness, leaving no money in cither Drive On's or IWC's account which could be traced and claimed by Citadel: Citadel, supra note 17 at 415 . L.D. Smith, The Law of Tracing (Oxford: Clarendon Press, 1997). Note the distinction taken by the author at 6-10 between following. where no substitution of the propeny has occurred, and tracing, where a claim is made to a substitute of the original thing. 
[T]he Bank received both a contractual undertaking to assume the obligations of Trojan in the event of its default, and security of a proprietary nature in support of that undertaking. The mortgage, as security for the guarantee, conferred on the Bank a proprietary interest in the trust property. The guarantee provided by Primary [one of the estate companies], supported by a collateral mortgage over property owned by Primary, in my view, constitutes property which can be made the subject of a knowing receipt claim. ${ }^{43}$

It is suggested that the majority were correct to hold that the guarantee obtained by the bank constituted property. But to focus, as lacobucci J. does, on the collateral support for the guarantee rather than on the guarantee itself, is to invite courts to distinguish between different types of guarantee for no obvious policy reason. It is not intuitively apparent why a bank making a loan on the strength of an unsecured guarantee can, at most, be held liable as a "knowing assister" of a breach of trust, requiring the plaintiff to prove the bank's dishonesty, in contrast to a bank which takes a secured guarantee whose liability, in the event that the guarantee was procured by a breach of fiduciary duty, is based on the less exacting criterion of constructive knowledge.

There seems no good reason for distinguishing between secured and unsecured lending for the purposes of imposing a receipt-based constructive trust. Lenders obtain a benefit from secured and unsecured guarantees alike, as long as they are legally enforceable. Security which can be called upon in the event of the principal debtor's default enjoys obvious advantages over the often speculative creditworthiness of unsecured guarantors, but both types of guarantee confer a benefit on a lender. The conclusion that a bank taking a guarantee, secured or unsecured, has received a benefit can be reached by one of two routes. The first, which side-steps juristic debates about the nature of property, is to invoke the unjust enrichment principle that is in the view of most commentators ${ }^{44}$ the foundation of the law of restitution. According to this principle, a bank is enriched whenever a borrower negotiates a legally binding guarantee because it has received value. A defendant who is unjustly enriched is one who has received value at the expense of the plaintiff without juristic reason. Value, for this purpose, is expansively defined to include money, goods or services. It includes, but is by no means co-extensive with, the receipt of title to property, and in the opinion of some theorists can include the economic use-value of property to which the defendant has no title, for example, because it has been stolen. ${ }^{45}$ Applying this approach, the giving of a guarantee enriches the bank since it has received the value of the right to sue another party, or to realize security, even though the benefit is contingent on the debtor's default.

An alternative route to the legal recognition of a guarantee as a benefit accepts the Supreme Court's assumption that a receipt-based constructive trust can only be awarded,

Ibid. at 400.

Contrast L. Smith, supra note 18.

P. Birks, "Mixing and Tracing: Property and Tracing" (1992) 45 Current Legal Problems 69; L.D. Smith, supra note 41 at 15-17. For a broad definition of enrichment in terms of enhanced spending power see P. Birks, "Property and Unjust Enrichment: Categorical Truths" (1997) New Zealand L. Rev. 623 at 654. 
even as a personal restitutionary remedy, against a defendant who has received a benefit which can be characterized as property. A chose in action clearly amounts to property for this purpose. There seems little doubt that the benefit of a guarantee agreement is a contractual chose in action. ${ }^{46}$ It is assignable as a legal chose in action, ${ }^{47}$ and the acquisition by a bank of the assets and choses in action of another bank carries with it the right to enforce a guarantee given by the other bank. ${ }^{48} \mathrm{~A}$ contract can subsist concurrently with a proprietary chose in action, a point perhaps overlooked by Sopinka J. in Gold v. Rosenberg when he denied that a guarantee was property on the ground that it was "no more than a contractual undertaking by the guarantor", enforceable in the event of the principal debtor's default. Proprietary analysis, therefore, as well as restitutionary theory, should have pointed the Supreme Court to the conclusion that the taking of a guarantee by a bank constitutes receipt for the purposes of equitable recipient liability.

\section{KNOWLEdGe, Notice and Strict Liabil.JTY}

Few topics in modern equity have attracted so much judicial exegesis as the question of the degree of knowledge required in order to hold a recipient of property liable as a constructive trustee. The numerous authorities in this area are irreconcilable, and arguably have obscured the true basis of recipient liability in equity. And yet paradoxically it is only by engaging in what at times appears to be an arid semantic debate on the meaning of knowledge that it is possible to come to an appreciation of the place of equitable recipient liability in the scheme of restitution. If courts can establish some principles for establishing the required degree of knowledge, rationally and not simply by bludgeoning the issue with a multiplicity of authorities, the rationale for the civil liability of recipients in equity should become clear, and by extension the relationship between the common law and equitable liability of recipients should become more intelligible. Although Gold v. Rosenberg and Citadel now constitute decisive appellate authority on the requisite degree of knowledge, the decisions cast only dim light on why that degree is considered necessary.

Some terminological ground clearing is a necessary preliminary to examining the various judicially-developed taxonomies of knowledge. The concepts of notice and knowledge are often used interchangeably but they need to be carefully distinguished.

Not all contractual rights can be conceptualized as property in this way. See G.H.L. Fridman, The Law of Contract in Canada, 2d ed. (Toronto: Carswell, 1986) at 631-34 for exceptions, such as contracts which create a personal tic and bar rights of action.

$\$ 7$

4X

Whealley v. Bastow (1855), 7 De G.M. \& G. 261; 44 E.R. 102.

Bank of Montreal v. Vineberg (1925), 43 Que. K.B. 363. The principles governing the assignment of guarantees are discussed in D.G.M. Marks \& G.S. Moss, Rowlatt on The Law of Principal and Surety, 4th ed. (London: Swect \& Maxwell, 1982) at 71 ; J.O. Donovan \& J.C. Phillips, The Modern Contract of Guarantee (Agincourn, Ont.: Carswell, 1985) at 506-12. The references made by Sopinka J. in Gold v. Rosenberg, supra note 16 at 405 to K.P. McGuiness, The Law of Guarantee, 3d ed. (Scarborough, Ont: Carswell, 1996) at 318-19 and Ilalsbury's Laws of England. 4th ed. (London: Butterworths, 1993), vol. 20, 50-65, 115-16, 123-24, do not contradict the chose in action analysis but simply define a guarantee in terms of an accessory contract. Assignment of the benefit of a guarantee is discussed by Halsbury at para 214 .

Gold v. Rosenberg, ibid. at 405. 
The nature of the distinction was explained by Megarry V.-C. in Re Montagu's Settlement:

In the books and the authorities the word "notice" is often used in place of the word "knowledge," usually without any real explanation of its meaning. This seems to me to be a fertile source of confusion; for whatever meaning the layman may attach to those words, centurics of equity jurisprudence have attached a detailed and technical meaning to the term "notice," without doing the same for "knowledge." The classification of "notice," into actual notice, consiructive notice and imputed notice has been developed in relation to the doctrine that a bona fide purchaser for value of a legal estate takes free from any equitable interests of which he has no notice.... It seems to me that one must be very careful about applying to constructive trusts either the accepted concepts of notice or any analogy to them. In determining whether a constructive trust has been created, the fundamental question is whether the conscience of the recipient is bound in such a way as to justify equity in imposing a trust on him."

Megarry V.-C. is here cautioning against an unthinking importation of the conveyancing meaning of "notice" into the law governing receipt-based constructive trusteeship. The conveyancing notion of constructive notice, which imposes upon a purchaser of land the duty to make reasonable inquiries into the existence of adverse equitable interests even in the absence of any evidence that such interests might exist, cannot be applied to a recipient of money or other property from a fiduciary. Outside the specialized law applicable to real estate conveyancing those who acquire property are under no duty to explore possible competing claims in equity to the property in the absence of some indication that the transfer might be defective. Megarry V.-C. also suggested ${ }^{\text {s1 }}$ that the doctrine of imputed notice, whereby the knowledge of an agent is imputed to the principal, does not apply to equitable recipient liability.

This distinction between notice and knowledge was obliterated in Gold v. Rosenberg by lacobucci J., who invoked a recent House of Lords decision, Barclays Bank v. $O^{\prime} B r i e{ }^{52}$ to reinforce the proposition that the bank had not made reasonable inquiries into whether the uncle had provided the guarantee for the loan in breach of the fiduciary obligations owed to his nephew. In $O^{\prime} B r i e n$, the House of Lords laid down guidelines that banks must follow if they are not to be put on 'constructive notice' of any undue influence or misrepresentation used by a debtor to procure a guarantee from someone with whom the debtor is in a close emotional relationship. ${ }^{53}$ In spite of some superficial factual similarities between $O^{\prime}$ Brien and Gold $v$. Rosenberg, the doctrine of constructive notice, as expounded in $O^{\prime} B r i e n$, does not seem particularly apt to define the degree of knowledge required to hold a recipient liable as constructive trustee. The $O$ 'Brien guidelines apply to banks and other lenders proposing to lend money on the strength of a guarantee provided by a third party. Failure to apply the guidelines puts

[1987], Ch. 264 at 277.

Jbid. at 277-78.

[1994] I A.C. 180 (II.L.(E.)) [hereinafter O'Brien].

In family guarantees and other transactions where there is "a substantial risk" of undue influence or other wrongdoing by a borrower, the bank must arrange a separate meeting with the guarantor, explain the nature of the transaction and the extent of the risk she is running, and urge her to take independent legal advice: ibid. at 97, Lord Browne-Wilkinson. 
a bank at risk of having the contract of guarantee set aside in the event that it has been procured by undue influence or misrepresentation. Recipients of property from fiduciaries, on the other hand, will usually ${ }^{54}$ be volunteers. It is unrealistic to apply the doctrine of constructive notice, either in the conveyancers' sense or in the rather special sense used in $O^{\prime} B r i e n$, to voluntary recipients of money or other property. Donees cannot, in the usual course of things, be expected to undertake the inquiries undertaken in "repeat transactions" such as conveyances or family guarantees.

A second objection to lacobucci J.'s reliance on the $O^{\prime}$ Brien guidelines is that it used the term "constructive notice" in an artificial and possibly misleading sense. The role of the doctrine of notice is to determine priority where two or more transactions affecting property have been entered into. But in $O^{\prime}$ Brien and Gold v. Rosenberg the doctrine of constructive notice was applied to only one transaction, namely the procuring of a guarantee in breach of an equitable obligation. ${ }^{\text {s }}$ In place of the carefully constructed jurisprudence governing the priority of interests created by successive transactions, the doctrine of notice is being invoked rather more crudely to "balance the equities" between a victim of a breach of fiduciary duty and a recipient of the proceeds of the breach. If $O^{\prime}$ Brien has any part to play in this area of equity it should be narrowly confined to providing guidance to banks taking guarantees on what steps they must take in order to avoid being fixed with "knowledge" of a prior breach of fiduciary duty. Even in that specific context the outcome of applying the guidelines will generally be the imposition of a more onerous regime on banks than on other recipients of money. Failure to apply the guidelines may result in a bank being held liable to make restitution in equity even though it was totally unaware of facts which should have induced it to inquire into possible equitable wrongdoing. It seems preferable to abandon all recourse to 'notice,' whether in the conveyancing or the $O^{\prime}$ Brien sense, and to impose liability on some other basis.

At the risk of oversimplifying an incorrigible body of case law, the authorities on knowledge can be reduced to three basic approaches. Each approach reflects certain assumptions, often concealed in the judgments, as to the nature and function of equitable recipient liability.

\section{A. The Dislionesty, or Conscience, Approacu}

The liability to compensate imposed on those who assist in a breach of fiduciary duty under the "second limb" of Barnes v. Addy ${ }^{56}$ requires proof of the actual knowledge, or dishonesty, of the assister. This basis of accessory liability was confirmed by the Supreme Court in Air Canada v. M\&L Travel where it was stated that

Not invariably, of course. Gold $\mathrm{y}$. Rosenberg is an exception since the bank provided consideration for the guarantee, which may explain why rescission cases such as $O^{\prime}$ Brien appeared to the Supreme Court to be analogically compelling. O'Sullivan, "Undue Influence and Mistepresentation after O'Brien: Making Security Sccure" in Rose, ed., supra note 7, 42 at $43-46$. 
"constructive notice was insufficient to bind the stranger's conscience so as to give rise to personal liability."\$?

Some authorities have applied the same test of dishonesty to the equitable liability of recipients on the ground that the moral basis for intervention by a Court of conscience should be identical under both limbs of Barnes $v$. Addy. ${ }^{58}$ If a uniform test of knowledge is imposed on assisters and recipients alike there can be little point in preserving the two limbs of Barnes v. Addy. Schemes for an integrated model of participatory liability have in fact been advanced, although not necessarily premised on the assumption that dishonesty should constitute the basis of liability. ${ }^{39}$

In Gold v. Rosenberg and Citadel the Supreme Court rejected the siren calls of Conscience and the attractions of an integrated model of secondary liability. It was wise to do so. The two limbs of Barnes v. Addy protect different interests and pursue different policy goals. As Lord Nicholls stated in the Privy Council decision of Royal Brunei Airlines v. Tan, "recipient liability is restitution based; accessory liability is not." ${ }^{160}$ Liability for assisting in a breach of fiduciary obligation is in substance an equitable tort, similar to the common law tort of conspiracy. The separate evolution of common law and equitable doctrine, which has constituted probably the most significant obstacle to the development of a rational private law based on an integrated system of remedies, has also meant that until recently the compensatory function of equitable accessory liability has been overlooked." ${ }^{61}$ But, as the Supreme Court recognized, equitable recipient action is not tortious. The analytical pattern of the "first limb" of Barnes v. Addy adopts the classic pattern of subtractive unjust enrichment, in that it restores to the plaintiff the value of wealth to which she was entitled in equity and of which she has been deprived unjustly (or, in the Pettkus v. Becker formulation, without juristic reason). ${ }^{62}$ It would be wrong to amalgamate and hence to confuse the essentially tortious "knowing assistance" action, where the basic aims are to compensate and perhaps to deter, with the restitutionary "knowing receipt" action, where the policy objective is the narrowly restorative one of reversing unjust enrichment.

Supra note 4 at 609.

Carl Zeiss Stifung v. Herbert Smith (No. 2), [1969] 2 Ch. 276 (C.A.); Re Montagu's Setlement, [1987] I Ch. 264; Canadian Imperial Bank of Commerce v. Valley Credit Union (1990), 63 D.L.R. (41h) 632 (Man. C.A.); Bullock v. Key Property Management (1997), 33 O.R. (3d) 1 (C.A.). Although not a decision on the reccipt-based constructive trust, the leading majority judgment of Lord Browne-Wilkinson in Westdeutsche Landesbank Girozentrale v. Islington London Borough Council, [1996] A.C. 669 at 705.706 (H.L.(E.)), is suffused by a strong "conscience" approach which might find favour in later English decisions. Some New Zealand authority has applied a test based on actual knowledge: Powell v. Thompson, [1991] I N.Z.L.R. 597 (H.C.), Equiticorp Industries Group v. Hawkins, [1991] 3 N.Z.L.R. 700 (H.C.).

Equiticorp Finance v. Bank of New Zealand (1993), 32 N.S.W.L.R. 50 at 104-105 (C.A.), Kirby P.; P. Finn, "The Liability of Third Partics for Knowing Receipt or Assistance" in D.W.M. Waters, cd., Equity, Fiduciaries and Trusts (Toronto: Carswell, 1993) 195.

Supra note 4 at 386.

P. Sales, "The Tort of Conspiracy and Civil Secondary Liability" (1990) Cambridge L.J. 491 at 508.

But see L.D. Smith who has suggested that "knowing receipt" is the "equitable analogue of conversion": "Tracing and Electronic Fund Transfers" in Rose, ed., supra note 7 at 125 . See also the reply of P. Birks, "The Burden on the Bank" in the same volume, at 205-206. 


\section{B. The Property Appkonch}

A second line of authority holds recipients liable in equity on the basis of their actual or constructive knowledge. ${ }^{63}$ It was this approach which found favour with the Supreme Court in Gold v. Rosenberg and Citadel. Prior to these decisions, it is probably fair to say that it reflected a preponderance of authority in common law jurisdictions. A test based on the concept of actual or constructive knowledge invites the drawing of analogies with the doctrine of notice in property law. These analogies are in fact misleading, and it will be submitted that the Supreme Court judgments are vitiated by a confusion between the personal and proprietary responses to unjust enrichment.

In evaluating a test of recipient liability based on actual or constructive knowledge, two questions are critical. The first is semantic: what is meant in this context by "constructive knowledge"? The second question is substantive: what is the rationale for imposing equitable liability on the basis of constructive knowledge?

A starting point for answering the first question is a typology of knowledge propounded by Gibson J. in Baden v. Société Générale pour Favoriser le Développement du Commerce et de l'Industrie en France $S A^{64}$ which has influenced subsequent judicial analysis. Gibson J. distinguished five types of knowledge:

(i) actual knowledge;

(ii) wilfully shutting one's eyes to the obvious;

(iii) wilfully and recklessly failing to make such inquiries as an honest and reasonable person would make;

(iv) knowledge of circumstances which would indicate the facts to an honest and reasonable person; and

(v) knowledge of circumstances which would put an honest and reasonable person on inquiry.

This calculus of knowledge has proved resilient in spite of an occasional criticisms that it is over-subtle ${ }^{65}$ and attempts to reconfigure it in terms of standards of commercial honesty. ${ }^{66}$ The significance of the scale lies as much in what does not constitute knowledge as in what does: the conveyancing doctrine of constructive notice, which

in Authorities include: Selangor United Rubber Estates v. Cradock (No. 3), [1968] 2 All. E.R. 1073 (Ch. Div.); Groves - Raffin Construction v. Bank of Nova Scotia (1975), 64 D.L.R. (3d) 78 (B.C.C.A.); Carl B. Potter v. Mercantile Bank of Canada (1980), 112 D.L.R. (3d) 88 (S.C.C.); El Ajou v. Dollar Land Holdings, supra note 5. [1992], 4 All. E.R. 161 at 235 (Ch. Div.) [hereinafter Baden]. Agip (Africa) v. Jackson, supra notc $S$ at 293, Millet J; Equiticorp Finance v. Bank of New Zealand, supra note 59 at 103-105, Kirby P.; Royal Brunei Airlines v. Tan, supra note 4 at 391, Lord Nicholls.

Cowan de Groot Properties v. Eagle Trust, supra note 3 at 76I, Knox J. ("the court will impute knowledge, on the basis of what a reasonable person would have learnt, to a person who is guilty of commercially unacceptable conduct in the particular context involved"). 
imposes a duty to make inquiries even where the facts do not suggest the existence of such interests does not appear on the list.

It is symptomatic of the terminological confusion pervading this area of equity that there is some uncertainty as to which of these five types of knowledge constitutes "constructive knowledge." In Baden Gibson J. classified all types except type (i) (actual knowledge) as constructive knowledge. On this analysis, "the court will treat a person as having constructive knowledge of the facts if he wilfully shuts his eyes to the relevant facts which would be obvious if he opened his eyes, such constructive knowledge being usually termed (though by a metaphor of historical inaccuracy) 'Nelsonian knowledge."'67 In contrast, the judgments in Gold v. Rosenberg and Citadel limited constructive knowledge to types (iv) and (v) even though the Baden typology was apparently approved and adopted. ${ }^{68}$ In Citadel, Lloyds Bank was held liable because it possessed constructive knowledge, defined by La Forest J. to be "knowledge of facts sufficient to put a reasonable person on notice or inquiry." Constructive knowledge was declared to be the touchstone of equitable liability. What constructive knowledge denotes remains open to argument.

The answer to the second question, relating to the rationale for fixing constructive knowledge as the standard for receipt-based liability, turns on the Supreme Court's conception of the constructive trust. The Court's model is essentially proprietary: the constructive trust resembles an express trust with the vital difference that it is created not by the act of a competent settlor but by operation of law. It is consistent with what might be termed a classical, proprietary model of the constructive trust, that the plaintiff can enforce her claim against all recipients save those who have actual or constructive knowledge of the trust. The beneficiary is entitled to the disputed property, albeit with the proviso that the strength of that entitlement may depend upon an application of the rules governing priority of property interests. The proprietary conception of the constructive trust informs the judgment of lacobucci J. in Gold v. Rosenberg:

Liability essentially turns on whether or not the defendant has taken property subject to an equity in favour of the plaintiff. The jurisprudence has long held that in order to take subject to an equity, a person need not have actual knowledge of the equily; notice will suffice. In my view, the same standard applies to cuses of knowing reccipt."

And in the same vein:

The plaintiff's claim amounts to nothing more than, "You unjustly have my property. Give it back." Unlike knowing assistance, there is no finding of fault, no legal wrong done by the defendant and no 
claim to damages. It is, at base, simply a question of who has a better claim to the disputed property. ${ }^{\text {.0 }}$

This analysis lends unintentional support to those who would like to banish the term "constructive trust" from the language of law." Whatever may be the juristic explanation of other species of constructive trust, it is an error to conceptualize the receipt-based constructive Irust as proprietary, or as some kind of analogue to the express trust with the judge acting as settlor. It is simply a formula for the award of personal, and not proprietary, restitution. In this respect it is no different from a constructive trust imposed on someone who assists the commission of a breach of fiduciary obligation, which is a formula for the award of the personal remedy of equitable compensation (or damages, if the fusion of common law and equitable compensatory remedies is recognized). A beneficiary who wants to vindicate title to property in fact has no need of a proprietary receipt-based constructive trust. The property can be followed or traced, applying the usual principles for identifying the property or its exchange-substitute. ${ }^{12}$ Once the tracing rules have established the evidentiary link between the plaintiff's title and the defendant's receipt proprietary, orders such as an equitable lien or a resulting or constructive trust can be imposed. ${ }^{73}$ These remedies will restore the property to the plaintiff, or at least ensure that its value is realized for her benefit. Indeed, it can be argued that Gold v. Rosenberg should not have been argued as a case about the receipt-based constructive trust at all. The nephew was simply following the assets held on trust for him which, in breach of trust, had been conveyed to the bank as security for the guarantee given by the uncle. On the view taken of the facts by the majority of the Supreme Court, it is likely the following or tracing claim would have been defeated by the bank's defence of good faith purchase. Nevertheless, the claim based on a receipt-based constructive trust was misconceived as it placed on the nephew the burden (which he failed to discharge) of establishing the bank's actual or constructive knowledge. In an action to follow or trace the property the onus of proof would have rested on the bank to show why it should not restore the trust assets to the nephew. The bank would have to show that it was a good faith purchaser of the trust assets without actual or constructive notice of the nephew's equitable title.

In contrast, Citudel illustrates the more typical, and correct, application of the receipt-based constructive trust as a personal remedy. Drive On or its parent company, IWC, had spent the trust money collected on behalf of Citadel, so no question of

no Jbid. at 399. The judgment of La Forest J. in Citadel, while apparently agreeing (at 434) with lacobucci $J$. in Gold v. Rosenberg. justifies the application of a test based on constructive knowledge in rather different terms. The rationale appears to be the need to maintain a differential standard between receivers and assisters in view of the fact that the former, but not the latter, are "necessarily enriched": Citadel, supra note 17 at 433-34.

7 P. Birks, "Trusts in the Recovery of Misapplied Asscts: Tracing, Trusts and Restitution" in E. McKendrick, ed., Commercial Aspects of Trusts and Fiduciary Obligations (Oxford: Clarendon Press, 1992) 149 at 153-56.

$n$ L.D. Smith, supra note 41.

" For a recent discussion on whether a lien or proportionate share should be awarded sce Foskett v. McKeown, [1997] 3 All. E.R. 392 (C.A.). 
following or tracing could arise. The bank was held personally liable to make restitution to Citadel of the money banked by Drive On and IWC. Personal recipient liability in equity fills an important gap in the scheme of private law remedies where it is impossible or impracticable to trace. But to impose personal liability as a constructive trustee on the basis of actual or constructive knowledge because, in the words of lacobucci J., "the plaintiff's claim amounts to nothing more than, 'You unjustly have my property. Give it back,"'"74 is to confuse the personal and proprietary models of the constructive trust. It is this confusion which underlies the Supreme Court's choice of constructive knowledge as the criterion of liability.

\section{Holding Recipients Strictly Liable}

The third approach, which would hold recipients strictly liable to make restitution for the value of property received in breach of fiduciary obligation, has been explored by Professor Peter Birks in a series of articles. ${ }^{75}$ His analysis had not received a great deal of judicial attention prior to Gold v. Rosenberg and Citadel. ${ }^{76}$ According to Professor Birks's scheme, the liability of recipients to make restitution in equity should be strict. As strict liability is not synonymous with absolute liability, restitutionary defences, such as change of position, good faith purchase and ministerial receipt (an agent's payment over of money or other property to the principal), ought to be available to the recipient. A recipient who possesses any of the "five degrees" of knowledge, applying the Baden scale of knowledge, should be held not to be in good faith for the purposes of establishing a restitutionary defence, such as change of position, which requires proof of good faith. In applying the Baden scale, however, a court must be sensitive to context, so that facts which would place a purchaser on inquiry in a conveyancing matter will not necessarily impose a duty of inquiry where they relate to a commercial transaction.

As La Forest J. recognized in Citadel, application of Professor Birks's regime of strict liability would not in practice result in very different outcomes from the Supreme Court's own "fault based" approach." The most significant practical difference it makes is to reverse the burden of proof. Instead of the plaintiff having to prove the defendant knew of a fiduciary wrongdoing, the bank or other recipient would have to

Supra note 17 at 399.

P. Birks, "Misdirected Funds: Restitution from the Recipient" (1989) Lloyd's Maritime and Commercial L.Q. 296; P. Birks, "Persistent Problems in Misdirected Money: a Quintet" (1993) Lloyd's Maritime and Commercial L.Q. 218; P. Birks, "Equity in the Modern Law: An Exercise in Taxonomy" (1996) 26 University of Western Australia L. Rev. I at 69-76. See also C. Harpum, "The Basis of Equitable Liability" in P. Birks ed., The Frontiers of Liability, vol. 1, (Oxford: Oxford University Press, 1994) 9. (f. S. Gardner, "Knowing Assistance and Knowing Reccipt: Taking Stock" (1996) 112 L.Q. Rev. 56.

76. Support for the proposal, or at least for its underlying logic, can be found in El djou v. Dollar Land Holdings, supra note 5, Millet J., rev'd on other grounds [1994] 2 All. E.R. 685 (C.A.); Koorootang Nominees Pry v. Australia and New Zealand Banking Group (23 June 1997), Victoria (Supreme Court), Hansen J. 
demonstrate its good faith, including absence of relevant knowledge, as a critical element of a defence such as change of position. ${ }^{78}$

The logic of Professor Birk's proposal for strict liability is compelling. The liability of recipients at common law, subject to the application of defences, is also strict. Restitution of a mistaken or stolen payment will not be denied on the ground that the victim of the mistake or theft was in some way at fault. ${ }^{79}$ The process of tracing and claiming property is also strict: the plaintiff must show that the property which has reached the defendant following a chain of substitutions represents value provided by the plaintiff, if necessary by invoking presumptions that the law makes against wrongdoers. The defendant's "knowledge" of the circumstances surrounding the transfer is only relevant, if at all, to establish a defence such as good faith purchase or change of position. It was suggested above that the nephew in Gold v. Rosenberg could have traced the estate assets. Upon proof the uncle had used trust assets as security for the guarantee the appropriate remedy might be, as lacobucci J. proposed, ${ }^{80}$ a declaration that the guarantee was unenforceable against the nephew. Relief would have been denied if the bank had shown that it was a good faith purchaser or had changed its position in good faith. It is inconsistent for the law to require a defendant to show good faith when a proprietary restitution is sought after the plaintiff has followed or traced property, and to place the burden on the plaintiff to show the defendant's knowledge or lack of good faith when personal restitution is sought in equity for the value of the property received. The tracing exercise necessary to identify the plaintiff's value in the hands of the defendant is identical in both cases, and there is no reason in principle why a plaintiff pursuing a personal claim to misappropriated property should be subject to a higher burden of proof than a plaintiff pursuing a proprietary claim.

In spite of their cogency, the arguments for strict liability were rejected by La Forest J. in Citadel. His reasons betray a misunderstanding of the relationship between personal and propriety restitution, as well as of the place of fault in the law of restitution.

In my view, the test formulated by Professor Birks, while not entirely incompatible with my own, may establish an unjust deprivation, but not an unjust enrichment. It is recalled that a plaintiff is entitled to a restitutionary remedy not because he or she has been unjustly deprived but, rather, because the defendant has been unjustly enriched, at the plaintifl's expense. To show that the defendant's enrichment is unjustified, one must necessarily focus on the defendant's state of mind not the plaintiffs knowledge, or lack thereof. Indeed, without constructive or actual knowledge of the breach of trust, the recipient may very well have a lawful claim to the trust property. It would be unfair to require a

It would, of course, not be sufficient for a recipient to prove good faith. Acts or omissions amounting to a change of position must also must be shown: Storthoaks (Rural Municipality) $v$. Mobil Oil Canada (1976), 55 D.L.R. (3d) I (S.C.C.).

Kelly v. Solari (1841), $9 \mathrm{M} \& W$ 54. It must be adinitted that there are signs that fault is becoming more relevant to the determination of mistaken payment cases under the guise of absence of juristic reason. See for example, McDiarmid Lumber v. Canadian Imperial Bank of Commerce (1992), 94 D.L.R. (4th) 227 (B.C.S.C.). 
recipient to disgorge a benefit that has been lawfully received. In those circumstances, the recipient will not be unjustly enriched and the plaintiff will not be entitled to a restitutionary remedy."

A number of points can be made in answer to this defence of fault-based liability. First, a law of "unjustified" enrichment does not "necessarily" have to focus on the defendant's state of mind. The law may of course, in some areas, choose to do so. Restitution will then be, in Professor Birks's phrase, "defendant sided." ${ }^{22}$ An example is restitution of benefits procured by a defendant's unconscientious behaviour, where inquiry will naturally focus on whether the defendant exploited the plaintiff's vulnerable position. ${ }^{83}$ But the areas of restitution where proof of injustice necessitates an assessment of the defendant's fault or reprehensible behaviour are few in number, unless this dictum of La Forest J. presages their enlargement, perhaps by an expansive reading of the phrase "absence of juristic reason." The greater part of the law of restitution, including mistake, compulsion and failure of consideration, is concerned to explicate why the plaintiff did not intend to confer a benefit on the defendant. The defendant's state of mind is irrelevant to this inquiry. La Forest J. treats proof of the defendant's fault or knowledge as part of the paradigmatic structure of the law of unjust enrichment, when in fact it is a highly atypical feature of restitutionary claims.

Secondly, La Forest J. argues that a strict liability regime could result in a recipient being held personally liable to make restitution when in fact she might have a lawful claim to the property. While the boundary between personal and proprietary restitution remains unclear in some respects ${ }^{84}$ there are, as the law now stands, many situations in which a plaintiff can obtain personal restitution but where proprietary recovery will be denied, so that the recipient retains title to the property. ${ }^{85}$ A possible, if imaginative, reading of the latter part of La Forest J.'s dictum is that he considers that any unjust enrichment of the defendant should in principle entitle the plaintiff to a proprietary, as well as a personal, response, always provided that the plaintiff's value can be traced to the hands of the defendant. This proposition is controversial but

Supra note 17 at 435.

nz Birks, Restitution - The Future (Sydney: Federation Press, 1992) al c. 2.

n Louth v. Diprose (1992), 175 C.L.R. 621 (H.C. of A.).

nt For a discussion, in the imatrimonial home contexl, see Peler v. Beblow (1993), 101 D.L.R. (4th) 621 at 649-52, Mcl.achlin J. Ste also D.M. Paciocco, "The Remedial Constructive Trust: $\wedge$ Principled Basis for Priorities Over Creditors" (1989) 68 Can. Bar Rev. 315; E.L. Sherwin, "Constructive Trusts in Bankruptcy" (1989) University of Illinois L. Rev. 297. An important contribution to this debate has been made by R. Chambers, "Resulting Trusts and Restitution" in Resulting Trusts (Oxford: Clarendon Press, 1997) Part Il, at 233-236.

The converse situation, of allowing proprietary restitution but denying a personal remedy, is rarer. Sinclair v. Brougham, [1914] A.C. 398 (H.L.(E.)) was one such case. In Westdeutsche Landesbank Girozentrale v. Islingion London Borough Council, supra note 58 Lord Browne-Wilkinson disapproved at 709-14 of this aspect of Sinclair v. Brougham and held, at 714, that a claimant of money under a void contract "has a personal action at law to recover the moneys paid as on a total failure of consideration; he will not have an equitable proprietary claim which gives him rights against third parties or priority in insolvency; nor will he have a personal claim in equity, since the recipient is not a trustec." This proposition creates, at least for void contracts, precisely the disjunction between personal and proprietary restitution in English law which La Forest J. rejects for Canadian law. 
certainly defensible. ${ }^{86}$ Professor Birks' scheme of strict liability, far from being inconsistent with that proposition, actually promotes a coherent and integrated system of personal and proprietary responses to unjust enrichment. Proof by the plaintiff of the essential elements of the claim, and by the defendant of a recognized restitutionary defence, would be identical, save that proprietary restitution would not be awarded unless the plaintiff established the survival of her property into the hands of the defendant. Failure to do so would remit the plaintiff to a personal claim to restitution. Personal claims for restitution are already permitted against enriched parties who "have a lawful claim" to the enrichment, in the sense that a proprietary claim to the enrichment cannot be asserted. A regime of strict liability would actually reduce this particular remedial disjunction, not increase it.

\section{Conclusion}

The Supreme Court has in recent years handed down decisions on both limbs of Barnes v. Addy. Canadian law is in this respect more fortunate than other common law jurisdictions where the highest courts have rarely reviewed any form of participatory liability. ${ }^{87}$ Nevertheless, one comes away from reading Gold v. Rosenberg and Citadel with a sense that the Supreme Court, while correctly characterizing equitable recipient liability as restitutionary, appeared not to know what it means to say that a particular doctrine belongs to the law of restitution. ${ }^{88}$ The foundation concepts of "enrichment" and "unjust" (or "unjustified") never received the close analysis they invariably require. The work required to transform the equitable concept of "receipt," into the restitutionary touchstone of "enrichment" was not seriously begun. Indeed, by confining restitution to transfers to banks constituting "beneficial receipt" the Supreme Court may have undermined a verity of banking law that banks receive and apply all deposits beneficially. Similarly, the Supreme Court had a wonderful opportunity to do away with casuistic inquiries into degrees of knowledge, which have so disfigured this area of equity, but chose instead to preserve them by insisting that a plaintiff must establish constructive knowledge.

Finally, and most fundamentally, the Supreme Court has misunderstood the juridical nature of the receipt-based constructive trust. As a personal measure of restitution it has nothing to say about specific restitution of property or settling priority disputes; these matters can be safely left to the proprietary remedies awarded pursuant to a tracing inquiry. And so this article ends, as it began, with the fascination the constructive trust exerts over lawyers' minds. In the words of Professor Palmer, which have become

See articles, supra note 84.

Exceptions are Consul Development v. D.P.C. Estates (1975), 132 C.L.R. 373 (H.C.A.), Wesipac Banking Corporation v. Savin, [1985] 2 N.Z.L.R. 41 (N.Z.C.A.): Royal Brumei Airlines v. Tan supra note 4.

A symptom of this doctrinal incoherence, not discussed in the text, is the statement of la Forest J., supra note 17 at 437 , that the "imposition of liability as constructive trustee on the basis of 'knowing receipt' is a restitutionary remedy and should not be confused with the right to trace assets at common law or in equity." If there is an implication here that tracing is not restitutionary, or that it is analytically distinct from equitable constructive trust liability, it runs counter to much recent restitution scholarship. See L.D. Smith, supra note 41 at 29-33, c. 9. 
cliched by repetition, "[t]he constructive trust idea stirs the judicial imagination in ways that assumpsit, quantum meruit, and other terms associated with quasi-contract have never quite succeeded in duplicating." " In Gold v. Rosenberg and Citadel the Supreme Court was hypnotized by equitable terminology into believing that the constructive trust was a proprietary remedy. 